\title{
Konflik Dalam Novel Bidadari Bermata Bening Karya Habiburrahman El-Shirazy
}

\author{
Sahrul Umami ${ }^{1}$ \\ Fauzi Rahman ${ }^{1 *}$ \\ Ryan Hidayat ${ }^{1}$ \\ ${ }^{1}$ Universitas Indraprasta PGRI, Jakarta \\ Timur, DKI Jakarta, Indonesia \\ *email: fauzierachman20@yahoo.com
}

Received: 28 Agustus 2020

Accepted: 28 September 2020

Published: 30 September 2020

doi: $10.22236 /$ imajeri.v3i1.5480

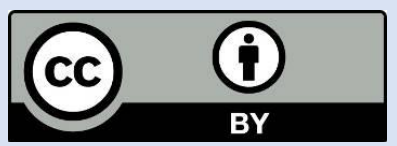

(c) 2020 Oleh authors. Lisensi Imajeri: Jurnal Pendidikan Bahasa dan Sastra Indonesia, Uhamka, Jakarta. Artikel ini bersifat open access yang didistribusikan di bawah syarat dan ketentuan Creative Commons Attribution (CC-BY) license.

(http://creativecommons.org/licenses/by/4.0/).

\section{Abstrak}

Konflik merupakan perselisihan atau pertentangan yang terjadi antartokoh dalam sebuah cerita. Selain itu, konflik dapat terbagi beberapa bagian yaitu konflik fisik, batin, dan sosial. Penelitian ini bertujuan mengetahui konflik dalam novel Bidadari Bermata Bening karya Habiburrahman El Shirazy. Penelitian ini menggunakan metode deskriptif kualitatif dengan teknik analisis isi, yaitu pendekatan yang dilakukan dengan cara menganalisis objek penelitian. Hasil penelitian ini menunjukkan bahwa terdapat 195 temuan konflik diantaranya: 1) konflik fisik 2) konflik batin dan 3) konflik sosial Simpulan penelitian ini, konflik paling banyak ditemukan yaitu konflik batin sebanyak 108 kutipan yaitu konflik batin yang dialami oleh Ayna karena ia menikah dengan laki-laki yang bukan pilihannya. Namun, Ayna bercerai karena suami terjerat kasus korupsi dan menemukan laki-laki yang Ayna cintai yaitu Gus Afif. konflik yang sedikit ditemukan yaitu konflik fisik sebanyak 23 kutipan yaitu meluapnya air sungai yang mengakibatkan rumah tinggal anakanak jalanan hancur. Rumah tinggal ini didirikan oleh Mbok Sani dan dibantu oleh Ayna dan teman-temannya.

Kata kunci: Konflik fisik; konflik batin; konflik sosial; novel; Bidadari Bermata Bening

\section{Abstract}

Conflict is a dispute or conflict that occurs between the characters in a story. In addition, conflict can be divided into several parts, namely physical, mental, and social conflicts. This study aims to see the conflict in the novel Bidadari Bermata Bening by Habiburrahman El Shirazy. This study uses a qualitative descriptive method with content analysis techniques, namely an approach that is carried out by analyzing the object of research. The results of this study indicate that: 1) the physical conflict that killed Mbok Sani because the river overflowed and burned the riverbank. 2) inner conflict, when Ayna who kept crying because Pakde and Bude (her uncle and aunt) rejected Pak Kyai and Bu Nyai's marriage proposal, and Gus Afiffelt sad that she was late in proposing Ayna. 3) social conflict, when Ayna who got some conflict with Pakde and Bude for pairing Ayna with Yoyok, the son of a rich merchant in his village. In conclusion, the conflict that arose more was the inner conflict that Ayna liked because she married a man who was not her choice. However, Ayna divorces because her partner is caught in a corruption case and finds the man Ayna loves, Gus Afif.

Keywords: Physical conflict, inner conflict, social conflict, novel, Bidadari Bermata Bening 


\section{PENDAHULUAN}

Pada masa sekarang ini perkembangan sastra sangat pesat, karena banyak karya sastra diciptakan oleh anak bangsa (Khusniyah, 2019). Sastra sebagai salah satu cabang seni yang dapat menyampaikan gagasan, ide, dan pengalaman. Hal ini senada yang dikemukakan oleh Semi (1990) bahwa sastra adalah salah satu cabang kesenian yang selalu berada dalam peradaban manusia yang di dalamnya dapat menangkap pengalaman hidup yang bermakna.

Salah satu perkembangan karya sastra yang terlihat yaitu novel. Novel merupakan karya sastra yang dapat mengemukakan sesuatu secara bebas dan berisikan cerita fiksi serta memberikan gambaran permasalahan lebih kompleks. Selain itu, novel juga perwujudan karya sastra modern yang menawarkan ruang yang lebih leluasa untuk penggambaran, penafsiran, dan dialog mengenai kehidupan sosial (Permata et al., 2014).

Sumardjo (1994) berpendapat bahwa, novel adalah cerita berbentuk prosa dalam ukuran yang luas, yaitu alur yang kompleks, karakter yang banyak, tema yang kompleks, setting yang beragam. Oleh karena itu, novel sebagai bentuk karya sastra yang dapat menceritakan segala permasalahan kehidupan secara kompleks dan runtut. Selain itu, dalam novel lebih banyak menampilkan karakter tokoh, serta alur yang susah ditebak oleh pembaca apabila pembaca tidak memahami secara baik.

Karya sastra yang baik khususnya novel harus mempunyai dua unsur pembangun yaitu unsur intrinsik dan ekstrinsik. Novel yang memiliki unsur-unsur intrinsik seperti tema, penokohan, latar/setting, sudut pandang dengan alur yang jelas sehingga pembaca dapat menikmati novel dengan baik. Sedangkan unsur ekstrinsik yaitu unsur yang ada dalam di luar sastra yaitu nilai pendidikan, sosial, religius, dan moral. Unsur-unsur pembangun dalam novel ini, apabila tersusun dengan baik dapat memudahkan pembaca dalam memahami maksud dan tujuan dari pengarang (Nurgiyantoro, 2010).

Karya sastra berbentuk novel biasanya mengandung sesuatu hal yang bermanfaat bagi manusia dalam menjalankan kehidupan sehari-hari. Seorang dapat membuat suatu cerita fiksi merupakan salah satu kegiatan axpresiasi sastra untuk meningkatkan daya pikir, ijaminasi, kepribadian, dan keterampilan bersastra. Selain itu, apresiasi sastra dapat melatih seseorang untuk memperhatikan dan mengenal diri sendiri dan lingkungan sekitar. Hal ini diperkuat oleh Effendi dalam Aminudin (2013) apresiasi sastra adalah kegiatan menggauli karya sastra secara sungguh-sungguh sehingga menumbuhkan pengertian, penghargaan, kepekaan, pikiran kritis, dan kepekaan perasaan yang baik karya sastra.

Dalam novel hal yang terpenting yaitu jalan cerita/alur. Alur merupakan serangkaian cerita yang berisikan tentang permasalahan atau peristiwa yang dialami oleh para tokoh yang ada dalam novel (Widayanti, 2012). Kosasih (2012) berpendapat bahwa alur merupakan pola pengembangan cerita terbentuk oleh hubungan sebab akibat. Pola-pola pengembangan cerita dapat kita jumpai antara lain, jalan cerita suatu novel kadang-kadang berbelit-belit, penuh kejutan, dan kadang sederhana.

Adanya alur/plot akan mempermudah pembaca dalam memahami dan manafsirkan permasalahan, peristiwa utama atau konflik yang ada dalam cerita (Novenia, Taum, dan Adji, 2019). Siswanto (2010) berpendapat konflik adalah ketegangan atau pertentangan antara dua kepentingan atau kekuatan di dalam cerita rekaan atau drama. Dalam novel alur sangat penting karena alur yang berisikan konflik sehingga membawa pembaca semakin menarik 
dalam membaca novel. Konflik yang dibuat penulis memberikan penguatan kepada pikiran pembaca sehingga pembaca tidak henti-hentinya untuk selalu membaca novel (Andari dan Amalijah, 2018).

Hal yang terpenting dalam alur adalah konflik, tetapi konflik dalam suatu cerita tidak bisa langsung terlihat secara tiba-tiba. Karena dalam pengembangan alur adanya tahap-tahap peristiwa dalam suatu cerita, tahap-tahap peristiwa itu meliputi: 1) tahap pengenalan, 2) tahap pengungkapan peristiwa, 3) tahap adanya konflik, 4) tahap puncak konflik, dan 5) tahap penyelesaian. Namun, tidak semua cerita harus dimulai dengan alur cerita dengan adanya pengenalan sampai penyelesaian (Kosasih, 2012)

Konflik dalam novel sebagai suatu bentuk pertentangan atau perselisihan yang muncul akibat dua kekuatan yang bertentangan, satu diantaranya diwakili oleh satu pribadi dan yang terjadi protagonis di dalam cerita dengan kekuatan alam, masyarakat, orang atau tokoh lain yang terjadi antagonis ataupun pertentangan dalam diri tokoh itu sendiri. Jadi, sebuah peristiwa dalam cerita konflik dapat digambarkan melalui perilaku, sikap, tokoh-tokoh yang terdapat dalam cerita, batin, dan sosial. (Sudjiman dalam Nugraha, 2019)

Sumardjo (1994) berpendapat, di dalam novel itu konflik digambarkan dengan pertarungan antara protagonis dengan antagonis. Protagonis adalah pelaku atau utama cerita sedangkan, antagonis adalah faktor pelawannya atau tokoh lawan protagonis. Antagonis tak perlu berupa manusia atau makhluk hidup lain, tetapi bisa juga situasi tertentu. Hal ini diperkuat oleh Nurgiyantoro (2010) bahwa, ada tiga jenis konflik yang selalu hadir di dalam cerita yaitu konflik fisik, konflik batin, dan konflik sosial. Jadi dapat dijelaskan, 1) Konflik fisik adalah konflik disebabkan adanya perbenturan antara tokoh dengan lingkungan alam; 2) Konflik batin adalah konflik disebabkan adanya perjolakan jiwa dalam hati seorang tokoh dalam cerita; dan 3) Konflik sosial adalah konflik disebabkan oleh adanya kontak sosial antarmanusia. Demikian, konflik adalah ketegangan atau pertentangan antara dua kepentingan mengenai suatu hal dari berbagai kepentingan. Selain itu, ada tiga jenis konflik yang selalu hadir di dalam cerita yaitu konflik fisik, konflik batin, dan konflik sosial. Dengan beragamnya konflik yang ada dalam cerita, ini membuktikan bahwa betapa pentingnya kehadiran konflik dalam suatu cerita (Meigita, 2018).

Dengan demikian terdapat penelitian yang terdahulu membahas tentang novel Bidadari Bermata Bening karya Habiburrahman El Shirazy, yakni Harti (2019) penelitiannya berjudul Psikologis Tokoh Utama dan Nilai Religius Novel Bidadari Bermata Bening Karya Habiburahman El-Shirazy. Pada penelitian ini menggunakan pendekatan kualitatif yang menekankan pada kutipan teks novel tersebut. Di dalamnya membahas tentang psikologis dan nilai religius, tetapi pada aspek psikologis yang dibahas diantaranya Id, Ego, dan Super Ego. Pada hasil pembahasan ini lebih banyak ditemukan yaitu unsur Id. Hal ini terlihat Ayna sebagai tokoh utama lebih sabar dalam menghadapi persoalan, menghormati dan menghargai pesan terakhir ibunya, patuh dan nurut, dan selalu menjalankan ibadah sebagai bentuk ketaatannya kepada Allah Swt.

Penelitian selanjutnya, yaitu Rohman (2020) yang berjudul Konflik Batin Tokoh Utama dalam Novel Bidadari Bermata Bening: Kajian Psikologi Sastra dan Implementasinya sebagai Bahan Ajar Sastra di SMP. Pada penelitian ini membahas konflik dibagi tiga bentuk diantaranya: 1) konflik mendekat-mendekat (Approach-Approach Conflict), konflik ini timbul 
jika sutau ketika terdapat dua motif yang semuanya positif. Wujud Konflik batin yang dialami Ayna setelah beberapa tahun hidup dengan suaminya, saat suami dan mertuanya terjerat kasus korupsi dia seperti dijadikan alat pembayaran untuk kebebasan mereka; 2) konflik mendekatmenjauh (Approach-Avoidance Conflict) konflik ini timbul jika dalam waktu yang sama timbul dua motif yang berlawanan mengenai satu objek, motif yang satu positif (menyenangkan), yang lain negatif (tidak menyenangkan). Wujud konflik batin yang dialami tokoh utama adalah ketika Ayna terpaksa menerima perjodohan yang dilakukan oleh Pakde dan Budenya demi keutuhan hubungan kekeluargaan antara dirinya dan keluarga Pakdenya; dan 3) konflik menjauh-menjauh (Avoidance-Avoidance Conflict) konflik terjadi apabila pada saat yang bersamaan, timbul dua motif yang negatif. Wujud konflik batin ketika alamarhumah ibunya dihina dan direndahkan oleh Neneng. Selanjutnya Ayna meminta Neneng untuk meminta maaf kepadanya tetapi malah terjadi perkelahian.

Berdasarkan kedua penelitian terdahulu di atas, terdapat kesamaan dari sudut pandang dalam menganalisis novel yaitu unsur psikologis serta perbedaan pada subfokus penelitian. Kemudian peneliti berusaha melakukan pembaharuan dalam artikel ini, yakni peneliti langsung memfokuskan analisis unsur konflik yang ada dalam novel dengan subfokus konflik fisik, batin, dan sosial. Dalam menganalisis ini akan terlihat konflik secara keseluruhan yang dalam novel, sehingga membuat pembaca dapat mengambil pelajaran untuk pengalaman pribadi pembaca.

Pada artikel ini peneliti memiliki tujuan penelitian yaitu untuk mengetahui konflik dalam novel Bidadari Bermata Bening serta cara penyelesaian yang dihadapi oleh tokoh pada novel tersebut. Novel ini terdapat beragam konflik disampaikan pengarang memuculkan konflik dari berbagai peristiwa dan persoalan yang sering muncul dalam kehidupan sehari-hari. Selain itu, novel ini memiliki relevansi dengan kehidupan sehari-hari, bahasa yang digunakan pengarang dalam novel mudah untuk dipahami oleh semua kalangan pembaca, dan memiliki pesan yang sangat berharga dalam memecahkan dan mencari solusi permasalahan hidup serta novel ini dapat dijadikan sumber inspirasi pembaca.

\section{METODE}

Penelitian ini menggunakan penelitian kualitatif dengan teknik analisis isi (content analysis). Ratna (2009) berpendapat sebagai penelitian kualitatif, data-data formalnya diambil dari teks novel Bidadari Bermata Bening karya Habiburrahman El Shirazy dalam bentuk kata-kata, kalimat dan wacana. Teknik analisis isi digunakan untuk menganalisis secara sistematis data atau isi serta pesan teks cerita. Moleong (2007)berpendapat bahwa dalam penelitian kulitatif data disajikan secara deskriptif. Sedangkan Emzir (2011) menambahkan deskriptif berupa data yang dikumpulkan berupa kata-kata, gambar, dan bukan angka- angka.

Teknik analisis menggunakan teknik analisis isi. Teknik analisis ini menggunakan suatu jenis analisis, di mana isi (teks tertulis) dikategorikan dan diklasifikasikan. Data-data yang didapatkan berupa kata-kata, kalimat, dan wacana dari novel Bidadari Bermata Bening karya Habiburrahman El Shirazy.

\section{HASIL DAN PEMBAHASAN}

Novel Bidadari Bermata Bening karya Habiburrahman El Shirazy merupakan termasuk novel inspiratif untuk pembaca. Dalam cerita novel ini pembaca dapat mengambil pesan dan 
pelajaran khususnya konflik yang ditampilkan oleh para tokoh. Selain itu, novel ini sudah dibaca oleh beberapa kalangan terkemuka untuk meningkatkan hasil novel ini.

Novel Bidadari Bermata Bening karya Habiburrahman El Shirazy tersebut dianalisis berdasarkan konflik yang terdapat dalam cerita yaitu konflik fisik, konflik batin, dan konflik sosial. Konflik fisik adalah konflik atau masalah yang disebabkan adanya perbenturan antara tokoh dengan lingkungan alam. Konflik batin adalah konflik atau masalah yang disebabkan adanya perjolakan jiwa dalam hati seorang tokoh dalam cerita. Sedangkan konflik sosial adalah konflik atau masalah yang disebabkan oleh adanya kontak sosial antarmanusia yang berwujud masalah perburuan, penindasan, percekcokkan, peperangan, atau kasus-kasus hubungan sosial lainnya (Nurgiyantoro, 2010).

\section{Analisis Konflik Fisik}

Konflik fisik adalah konflik yang disebabkan adanya perbenturan antara tokoh dengan lingkungan alam (Nurgiyantoro, 2010). Hasil analisis dan pembahasan konflik fisik yang terdapat dalam novel Bidadari Bermata Bening karya Habiburrahman El Shirazy. Ayna yang mengetahui keadaan jalanan yang berlubang karena hujan deras semalam. Ia selalu berhatihati ketika mengendarai motor karena ia tidak ingin terjadi apa-apa. Perhatikan kutipan di bawah ini yang memberikan penggambaran konflik fisik.

... ia harus segara tiba di Pasar Pahing Secang. Kalau terlambat, ia bisa tidak mendapatkan barang-barang yang diinginkan Bu Nyai, karena penjualnya terlanjur pulang. Ia tidak berani memacu lebih kencang, jalanan tampak licin karena masih basah oleh air hujan. Selokan di kanan-kiri jalan mengalirkan air cukup deras. Di beberapa tempat au selokan meluap sampai tengah jalan. Areal persawahan di kanankiri jalan tertutup air berwarna cokelat. Hujan malam tadi memang deras dan lama.

Kutipan di atas menunjukan bahwa penulis menggambarkan konflik fisik yaitu adanya permasalahan yang dihadapi Ayna ketika ingin pergi ke pasar Pahing Secang yakni Ayna yang mengetahui kondisi jalan menuju ke sana sehingga ia berhati-hati, terlebih ia mengetahui semalam telah hujan deras. Ia tidak berani memacu kendaraan lebih kencang karena kondisi jalanan yang berlubang bahkan banyak genangan air. Selokan dan area persawahan yang Ayna lewati tidak terlihat karena air membanjiri wilayah tersebut.

"Tari, kayaknya bakalan hujan. Bisa jadi deras. Aku khawatir aja sama anakanak. Kalau sungainya meluap bagaimana?"

"Nggak usah khawatir, Mbak, selama ini aman-aman saja."

"tidak bisa begitu, Lestari. Kau perhatikan nggak, itu rumah paling rendah di antara rumah-rumah lainnya. dan paling ringkih. Itu sebelumnya Cuma gudang barang rongsokan. Tiap malam kalau hujan turun aku selalu ingat anak itu. Nggak bisa tidur aku.

Ayna yang mempermasalahkan anak-anak jalanan yang tinggal di rumah pinggiran sungai bersama Mbok Sani. Hal ini membuat Ayna khawatir akan terjadi kenapa-kenapa yang menimpah anak jalanan itu. Karena Ayna mengetahui rumah yang ditempati sangat ringkih dan rendah dari rumah lainnya. Sehingga Ayna berpikir tidak menuntut kemungkinan ketika hujan deras, rumah itu akan hanyut terbawa derasnya aliran sungai. Ayna yang mempermasalah hal ini mempunyai inisiatif untuk mengajak anak-anak jalanan untuk mengungsi ke masjid terdekat ketika hujan turun. 
Hal ini menunjukkan adanya konflik fisik yang terjadi yaitu adanya permasalahan yang dihadapi oleh tokoh utama dalam cerita. Konflik fisik ini tidak terjadi hanya konflik secara sosial saja, melainkan bisa terjadi sebagai bentuk permasalahan dengan alam sekitar. Konflik fisik yaitu konflik yang disebabkan oleh benturan antara tokoh dengan lingkungan sekitar dan konflik sosial yaitu konflik yang terjadi antartokoh dengan tokoh yang lain (Alzuardi et al., 2019).

.... sebelum masuk ke kamar mandi ia meraih ponselnya yang sedang ia charge lalu membukanya. Ternyata Lestari menelepon tujuh kali sejak menjelang Subuh. Ia langsung menelepon Lestari.

"Ada apa, Tari?"

"Belum dapat kabar, Mbak? Nggak baca berita?"

"Berita apa?"

"Sungai itu meluap. Benar firasat Mbak Ayna! Untung anak-anak sudah kita ungsikan ke masjid.

"Mbok Sani bagaimana?” tanya Ayna penuh cemas.

"Hanyut bersama rumah itu."

"Inna illahi wa inna ilaihi roji"un"

"Inii saya dan Mila sedang menuju masjid itu. Anak-anak kita bawa ke rumah yang sedang kita siapkan itu saja yah Mbak?"

"Ya kamar-kamarnya kan sudah selesai dicat. Nanti kau beli karpet yang murah saja, sementara mereka tidur di lantai di atas karpet tidak apa. Sambil kita lengkapi semuanya. Hari ini saya harus ke Jakarta."

"Iya Mbak Ayna"

Wajah Mbok Sani yang tulus itu langsung terbayang di pelupuk mata Ayna. Kalau ajal sudah datang tak ada yang bisa mengurungkan. Bagaimana tidak? Mbok Sani dibujuk-bujuk tetap tidak mau tidur di masjid, ia pilih tetap di rumah kumuh di atas sungai itu. Ayna hanya berdoa semoga Allah mengampuni segala dosanya dan menerima segala amal baiknya. Meskipun miskin, Mbok Sani tidak pernah tinggal sembahyang dan sayang pada anak-aak jalanan.

Salah satu teman Ayna yang bernama Lestari berusahan menghubungi Ayna melalui handphone untuk memberitahukan kondisi rumah tinggal anak-anak jalanan. Namun, telepon dari Lestari tidak ketahui oleh Ayna ketika Ayna melihat handphone ada panggilan tidak terjawab dari Lestari. Ayna langsung menelepon Lestari untuk menanyakan sesuatu. Lestari dengan nada cemas memberitahukan ke Ayna kalau sungai yang dekat dengan rumah tinggal anak-anak jalanan dan Mbok Sani meluap. Sehingga membuat rumah tersebut hanyut dan hancur, anak-anak jalanan sudah ungsikan. Sedangkan Ayna yang cemas menanyakan keadaan Mbok Sani selama ini merawat anak-anak jalanan, tetapi Mbok Sani terbawa hanyut dengan rumah yang ditempati. Ayna langsung melafadzkan Inna illahi wa inna ilaihi roji'un.

Hal ini yang membuat khawatir Ayna kepada anak-anak jalanan dan Mbok Sani karena mereka tinggal di pinggiran sungai. Kemudian Ayna juga mengetahui kondisi rumah ditempati itu bekas gudang barang bekas, bahkan rumah itu lebih rendah dari rumah-rumah di sekitarnya. Kejadian ini membuat Ayna membayangkan musibah yang dialami oleh Mbok Sani dan Ayna juga mendoakan segala kebaikan Mbok Sani yang sudah merawat dan menyayangi anak-anak jalanan. 
Pada penggambaran di atas terlihat konflik fisik yang terjadi pada para tokoh dalam cerita, yaitu adanya konflik fisik yang berhubungan dengan alam sekitar. Secara tidak langsung adanya konflik fisik yang terjadi antartokoh dalam cerita. Konflik fisik atau konflik elementer diartikan adanya ketegangan antara tokoh-tokoh cerita yang berkaitan dengan perseteruan yang melibatkan anggota tubuh manusia. Selain itu, adanya perbenturan antara tokoh dan lingkungan alam (Etiwati et al., 2020).

\section{Analisis Konflik Batin}

Konflik batin adalah konflik atau masalah yang disebabkan adanya perjolakan jiwa dalam hati seorang tokoh dalam cerita. Konflik atau masalah yang dialami manusia dngan dirinya sendiri, ini lebih menekankan pada permasalahan intern manusia (Nurgiyantoro, 2010). Hasil analisis dan pembahasan konflik batin yang terdapat dalam novel Bidadari Bermata Bening karya Habiburrahman El Shirazy. Ayna yang merasakan keheranan ke Pakde dan Budenya karena ia mengetahui selama ini mareka tidak pernah memperlakukan Ayna dengan baik. Perhatikan kutipan di bawah ini yang memberikan penggambaran konflik batin.

Ayna masuk ke dalam kamarnya dan merabahkan badannya sesaat di kasur. Terasa nikmat. Kenangan bersama Ibunya di rumah itu hadir begitu saja. Ia memejamkan mata. Ia seperti dibelai oleh tangan halus ibunya. Bau bajunya yang khas seperti tercium olehnya. Kebahgiaan dan keindahan sesaat menyusup mengaliri syarafnya. Namun ia sadar sesuatu. Tiba-tiba keindahan itu seperti di lukisan kebun bunga yang sedap dipandang yang dirusak oleh coretan spidol. Apa sesungguhnya niat pakde dan budenya memperbaiki rumah itu? apakah akan dijual? Atau karena apa? Ia marasa ada yang aneh.

Kutipan di atas menunjukan bahwa penulis menggambarkan konflik batin yaitu Ayna yang sedang pulang ke kampung halamannya. Ia pulang ke rumahnya untuk membicarakan mengenai lamaran yang telah diajukan oleh Pak Kyai dan Bu Nyai yang di pesantren. Walaupun Ayna sudah menyatakan setuju yang diajukan, tetapi tidak lupa kalau ia memiliki Pakde dan Bude yang sudah dianggap orang tuanya setelah ibunya meninggal. Ayna pulang ke kampung halaman, sesampainya di depan rumahnya ia kaget melihat keadaan rumah berubah menjadi bagus tidak seperti biasanya.

Ketika Ayna istirahat, membuat Ayna bertanya-tanya dalam dirinya mengenai maksud dari Pakde dan Budenya telah membetulkan rumahnya menjadi bagus. Karena Ayna merasa selama ini Pakde dan Bude Ayna tidak menyenangkan bahkan tidak pernah memperlakukan Ayna dengan baik.

Malam harinya, Ayna tidak bisa tidur mencerna semua kejadian yang berlangsung selama Pak Kyai berkunjung di rumahnya. Ia masih belum sreg dengan jawaban Budenya yang tidak langsung menerima lamaran itu. Ia juga terus memikirkan kalimat yang dibisikkan ke telinganya di dapur ketika akan mengambil wudhu sebelum shalat zhuhur.

"Kamu yang sabar yah, Na, kalau misal nanti kenyataannya tidak seperti yang kau bayangkan. Kamu harus sabar.”

Terlihat batin Ayna yang belum bisa menerima jawaban dari Pakde dan Budenya karena tidak langsung menerima lamaran yang diajukan oleh Pak Kyai dan Bu Nyai. Sehingga membuat Ayna selalu bertanya-tanya atas jawaban yang diungkapkan oleh Pakde dan Budenya. Ditambah lagi ucapan Bu Nyai yang membisikan Ayna ketika di dapur sebelum 
mengambil air wudhu berbisik untuk sabar ketika kenyataan tidak sesuai dengan bayangan yang diinginkan. Bisikan Bu Nyai ini membuat Ayna semakin menaruh curiga ke Pakde dan Budenya memiliki rencana yang tidak baik untuk dirinya.

Ristiana (2017) mengemukakan bahawa konflik batin ini merupakan masalah intern bagi seorang manusia. Konflik batin ini ditunjukkan langsung oleh tokoh utama dalam cerita ini yaitu Ayna. Pada malam hari setelah Bu Nyai berbicara dengan Pakde dan Budenya, Ayna menaruh curiga kepada Pakde dan Budenya karena mereka tidak langsung menerima lamaran yang disampaikan oleh Bu Nyai. Selain itu, ditambah lagi bisikan yang disampaikan oleh Bu Nyai kepada Ayna sebelum salat zuhur.

Lelaki setengah baya itu lalu bangkit keluar meninggalkan ruang tamu rumah Ayna diikuti istrinya. Tangis Ayna kembali meledak. Dalam tangisnya terbit amarahnya. Jiwa berontaknya membela kehormatannya menyala. Ia bangkit menuju kamarnya dan mengemasi pakaian dan barang-barangnya. Detik itu tekadnya menyala bersama emosinya, ia kan kembali ke pesantren, tidak ada urusan dengan Pakde dan Budenya.

Namun ketika melangkah ke luar rumahnya dan menutup pintunya, pesan ibunya agar tidak memutus tali kekeluargaan kembali menggema dalam relung batinnya. Lalu kata-kata lembut Bu Nyai kembali terngiang di telinganya.

Adanya tekanan batin yang dirasakan Ayna karena Pakde dan Budenya tetap bersikeras akan menjodohkannya dengan anak dari saudagar kaya di kampungnya. Ayna terus menangis tidak bisa menerima keputusan Pakde dan Budenya, sehingga Ayna langsung berontak ingin membela kehormatannya dengan bergegas menyiapkan pakaian berniatan untuk kabur dan kembali ke pesantren.

Namun, ketika sampai di depan pintu Ayna teringat pesan terakhir yang disampaikan oleh Almh. Ibunya kalau Ayna tidak boleh memutuskan tali persaudaraan dengan Pakde dan Budenya, sehingga batin Ayna semakin menggema direlung hati Ayna. Dengan mengingat pesan dari terakhir Ibunya, Ayna tidak jadi pergi membuat hatinya luluh, karena ia berpikir pesan terakhir dari Almh. Ibunya sangat berarti untuk hidupanya. Selain itu, ia teringat pesan Bu Nyai walaupun Pakde dan Bude Ayna sudah menolak lamaran Ayna tetap akan menjadi anggota keluraga Bu Nyai.

Bu Nyai Nur Fauziyah meraih surat undangan itu dan membacanya. Air matanya menetes di sana. Usai membaca, ia menyerahkan kepada Pak Kyai. Ayna hanya diam dengan air mata meleleh di pipi. Gus Afif mengambil satu dan membacanya. Ia menahan peri luar biasa dalam dadanya. Seluruh tubuhnya gemetaran. Ia mencoba menguatkan dri dan bertahan.

"jadi kami datang terlambat?” Bu Nyai terisak. Suara parau.

Ayna hanya mengangguk, lalu tangis meledak.

Gus Afif merasa tidak kuat lagi menyangga kepalanya. Ia merasa roboh di atas tikar. Kepala pemuda itu menimpa tumpukan surat undangan pernikahan gadis yang ia dambakan.

Dibalik itu semua ada seorang laki-laki yang bernama Gus Afif yang tidak lain anak dari Pak Kyai dan Bu Nyai. Gus Afif diam-diam mencintai Ayna selama ia masih di pesantren. Gus Afif selalu perhatikan Ayna dan menaruh harapan besar untuk melamar Ayna menjadikannya istri. Suatu ketika Gus Afif ingin memberikan undangan pernikahan Kyai Yusuf ke Ayna, Gus Afif mengutarakan semua perasaan yang ia miliki. Gus Afif sebelum 
pulang telah berjanji akan membahagiakan Ayna dan ia juga akan membawa Pak Kyai dan $\mathrm{Bu}$ Nyai untuk datang melamar Ayna.

Ketika Gus Afif datang ke rumah Ayna dengan Pak Kyai dan Bu Nyai. Bu Nyai meraih undangan yang diberikan oleh Ayna. Setelah membaca undangan tersebut Bu Nyai menangis dan memberikan undangannya ke Pak Kyai. Ayna hanya diam dan air matanya meleleh di pipi. Ketika Pak Kyai membaca undangan itu, Gus Afif mengambil satu ditumpukkan undangan yang ada dihadapan Ayna.

Gus Afif tidak kuasa ketika membaca surat undangan itu, karena ia membaca wanita yang dicintai akan menikah dengan laki-laki lain. Gus Afif bertanya kepada Ayna bahwa dirinya datang terlambat, Ayna menganggukan kepalanya dan menangis. Kepala Gus Afif tidak kuat menyangga dan badan Gus Afif langsung lemas dan terjatuh ketika hal itu terjadi kepada dirinya.

Konflik batin ini langsung digambarkan pada para tokoh central yang ada dalam cerita. Para tokoh secara langsung mengalami pergejolakan batin yang langsung dirasakan sehingga tokoh langsung merasakan kesedihan. Selain itu, konflik batin para tokoh langsung tergambar dalam dialog dalam sebuah cerita fiksi. Konflik batin adalah konflik yang dialami manusia dengan dirinya sendiri atau biasa disebut dengan permasalahan intern seorang individu. Konflik batin ini merupakan konflik yang umumnya dialami tokoh utama dalam cerita rekaan (fiksi) (Diana, 2016).

Setiap malam ia terus menangis kepada Tuhan Yang Maha Kuasa agar melindungnya dengan memberikan jalan ke luar dari segala jerat kezaliman. "Jagalah kesucianku, Ya Allah sebagaimana Engkau menjaga kesucian Asiyah dari jahatnya Fir'aun," isaknya dalam sujudnya.

Ayna yang selalu bersedih dan berdoa kepada Allah swt., agar dirinya tidak selalu terzalimi dan selalu terjaga kesuciannya, serta meminta jalan ke luar mengenai cobaan yang diberikan kepada hamba-Nya. Dengan banyak berdoa dan mendekat diri kepada-Nya, Ayna yakin akan bisa menyelesaikan masalah yang ia hadapi.

Tubuh Ayna bergetar hebat tapi dia berusaha keras menguasi dirinya. Ingin rasanya menonjok dan menendang mertuanya itu. Ia merasa bernar-benar dihina. Mertua mana yang rela menjual anak menantunya kepada lelaki tua bandot yang busuk. Dan kepada Yoyok, ia tidak bisa memaafkan, bagaimana ia bisa mengizinkan hal ini.

Batin Ayna langsung menjerit dan tubuh Ayna gemetaran setelah mendengar apa yang diungkapkan oleh mertuanya. Ayna tidak menyangka mertuanya akan menjodohkan Ayna dengan Brams, laki-laki yang bisa membebaskan mertua dan suaminya dalam kasus korupsi. Dengan mendengar itu Ayna begitu kesal ingin langsung menendang dan menonjok mertuanya, ketika mertuanya berbicara hal itu dihadapannya. Sedangkan Ayna tidak menyangka dan tidak memaafkan kalau Yoyok menyetujui dan mengizinkan rencana yang telah dibicarakan oleh Pak Kusmono yang merupakan orang tua Yoyok. Hal ini dapat diperjelas bahwa konflik menyaran pada sesuatu yang bersifat tidak menyenangkan yang terjadi dan atau dialami oleh tokoh cerita, jika tokoh mempunyai kebebasan untuk memilih, ia tidak akan memilih peristiwa itu menimpa pada dirinya (Nurgiyantoro, 2010)

\section{Analisis Konflik Sosial}

Konflik sosial adalah pertentangan yang terjadi akibat kontak sosial manusia denganmanusia lainnya (Saputri et al., 2016) .Konflik sosial ini disebabkan oleh adanya kontak sosial antarmanusia yang berwujud masalah perburuan, penindasan, percekcokkan, 
peperangan, atau kasus-kasus hubungan sosial lainnya. Hasil analisis dan pembahasan konflik sosial yang terdapat dalam novel Bidadari Bermata Bening karya Habiburrahman El Shirazy. Ayna yang cekcok dengan temannya di pesantren karena Neneng memfitnah Ayna anak seorang TKW dan hasil hubungan gelap Ibunya ketika menjadi TKW. Ayna yang tidak senang langsung mendatangi Neneng dan menegurnya. Perhatikan kutipan di bawah ini yang memberikan penggambaran konflik batin.

"Yang paling kasihan menurutku si Ayna. Lihat aja, dia paling-paling akan meneruskan ibunya jadi TKW. Buah tak akan jatuh jauh dari pohonya! Nilai UN-nya yang kebetulan tinggi tak akan menolongnya sama sekali!” Nyinyir Neneng yang tidak menyadari bahwa Ayna yang ia gunjing telah sampai di sampingnya bersama Zulfa.

"Jaga mulutmu, Neng!"

Kata-kata Ayna tegas membuat kaget Neneng dan semua yang ada di situ. Seketika suara riuh mereka sirna sesaat.

"Aku punya salah apa sih padamu, Neng? Apa aku pernah menjahili kamu? Pernah menyakiti kamu, sampai kau terus menghinaku? Hah!"

"Siapa yang menghinamu, santai ajah!'

"Kau kira aku tidak dengar? Kau kira aku tidak tahu?"

"Kau terlalu sensitive, Na. nggak usah sombong nilai UN-mu paling tinggi, terus sensitive begitu!"

"Sensitive? Sombong? Apa nggak kebalik. Okelah, aku maafkan segala penghinaanmu pada diriku. Terserah, kau boleh mengatakan apa saja tentang diriku, Neng. Tapi, tidak tentang Ibuku! Kau tidak aku maafkan atas penghinaanmu pada Ibuku, kecuali..."

Kutipan di atas menunjukan bahwa penulis menggambarkan konflik sosial yaitu Ayna mendatangi Neneng di halaman sekolah yang sedang menjelekan nama baik Ayna dihadapan teman-teman. Neneng menjelek-jelekan hasil UN Ayna yang mendapatkan nilai tertinggi dan memfitna Ibu Ayna. Ayna mendengar secara langsung apa yang dikatakan oleh Neneng, Ayna dengan suara keras langsung membentak Neneng, sehingga teman-temannya kaget ketika Ayna bisa seperti itu. Ayna meminta Neneng mencabut omongan yang tidak benar itu dan meminta maaf kepadanya. Namun, Neneng yang sangat benci dengan Ayna tidak ingin minta maaf kepada Ayna bahkan Neneng menantang Ayna. Ayna sebenarnya sudah memaafkan penghinaan yang lontarkan oleh Neneng dihadapan teman-teman. Namun, hal yang membuat Ayna marah yakni tidak terima Ibunya dihina.

Pada gambaran di atas terlihat adanya konflik, yaitu seorang yang berusaha ingin menghancurkan dan membuat orang lain malu dihadapan orang lain serta menyebarkan informasi yang belum tahu benar atau salahnya. Konflik sosial yakni dapat dikatakan sebagai suatu proses sosial diantara dua pihak atau lebih ketika pihak yang satu berusaha menyingkirkan pihak yang lain dengan cara menghancurkan atau membuatnya tidak berdaya. Latar belakang adanya konflik adalah terdapat adanya perbedaan yang sulit ditemukan kesamaannya atau sulit untuk didamaikan secara dua belah pihak, baik itu perbedaan dalam segi biologis atau dalam segi ekonomis seperti kepandaian, ciri fisik, pengetahuan, keyakinan, dan adat istiadat (Nugraha, 2019).

Ini sudah jadi keputusan Pakde! Tidak bisa diubah lagi!"

"Pakde, tolong dengarkan Ayna, yang akan menjalani Ayna, Pakde. Tolong Pakde jangan Tolak Lamaran Itu! Ayna sudah mantap menerima lamaran itu, Pakde.” 
Numun rintihan dan permintaan penuh mengiba itu tidak juga menggoyahkan hati Darsun.

"Tidak! Pakde tidak mungkin merestui kau menikah dengan duda beranak dua. Tidak! Na Pakde sudah mikirkan sangat matang. Sudah minta petunjuk Gusti Allah bermalam-malam. Pakde ingin kau hidup mulia. Pakde sudah mendapatkan calon untukmu."

Terlihat maksud dari bisikan oleh Bu Nyai ketika di dapur sebelum mengambil air wudhu dan Pakde dan Budenya tidak langsung menerima lamaran yang diajukan oleh Pak Kyai dan Bu Nyai. Pakde dan Budenya sudah merencanakan kalau lamaran itu ditolak karena Pakde Ayna merasa Ayna tidak pantas menikah dengan laki-laki duda yang sudah memiliki anak. Ayna terus berusaha meyakinkan Pakdenya untuk tetap menerima lamaran itu, karena Ayna merasa sudah mantap dengan lamaran yang diajukan oleh Pak Kyai dan Bu Nyai.

Dengan Ayna terus merintih dan menangis Pakde tidak memperdulikan dan tidak goyah atas keputusannya. Pakde memberikan alasannya kalau Pakde menolak karena Ayna tidak cocok menikah dengan laki-laki duda dan Pakde sudah memikirkan secara matang-matang. Karena Pakde dan Bude Ayna ingin menjodohkan Ayna dengan anak dari saudagar kaya di kampungnya.

Dengan memakai silet, ia merobek tasIbu itu dan ia ambil dompetnya. Lalu purapura jalan dengan sangat tenang. Ibu itu sama sekali tidak merasa apa yang terjadi dengan tasnya. Ayna langsung lari dan memegang jaket pemuda itu.

"Berhenti!" teriak Ayna.

Pemuda itu agak kaget.

"Ada apa, Mbak?"

"Kembalikan dompet Ibu itu!"

"Dompet apa?" Muka pemuda itu pucat. Orang-orang langsung memandanginya.

"Tolong semuanya pegangi pemuda ini. Dia copete!"

"Jangan asal bicara, yah!"

"Tolong, amankan copet ini! Dia menyobek tas Ibu itu lalu mengambil dompetnya. Dimasukkan di saku celananya! Kalau tidak geledah saja!” Hlm. 255-256.

Ayna melihat copet berusaha mensilet atau merobek tas seorang Ibu dan mengambil dompet yang berada dalam tas ibu tersebut. Namun, Ayna brusaha berteriak berhenti. Ayna langsung meminta pencopet itu mengembalikan dompet yang diambil dari tas ibu tersebut. Pencopet itu berusaha mengelak dengan muka pucat dan Ayna meminta orang-orang memegangi pencopet itu. Pencopet itu terus berusaha mengelak kalau ia bukan pencopet, tetapi Ayna memberitahu pencopet ini merobek tas Ibu tersebut dan menaruh dompetnya di saku celananya. Lalu Ayna meminta seseorang menggeladah saku celana itu ternyata dompetnya pun ada.

\section{KESIMPULAN}

Berdasarkan pembahasan di atas, dapat disimpulkan bahwa dalam novel Bidadari Bermata Bening terdapat konflik sesuai dengan teori yang digunakan yaitu konflik fisik, konflik batin, dan konflik sosial. Ketiga konflik ini sangat terikat di dalam karya sastra karena konflik merupakan salah satu alur cerita yang tidak lepas dari sebuah karya sastra. Konflik yang paling dominan dalam analisis ini ialah konflik batin yaitu terdapat tokoh Ayna yang merasakan kesedihan karena Ayna telah dijodohkan oleh Pakde dan Budenya dengan Yoyok 
anak saudagar kaya di kampungnya. Ayna dijodohkan karena Pakde dan Budenya akan diberikan imabalan jika berhasil menjodohkan Ayna dengan Yoyok. Selain itu, konflik batin terdapat pada tokoh Gus Afif merasa dirinya tidak berarti karena Gus Afif telah mencurahkan isi hatinya kepada Ayna, tetapi Gus Afif terlambat untuk datang ke rumah Ayna sehingga Ayna sudah dilamar oleh Yoyok.

Adanya konflik dalam sebuah novel membuat pembaca semakin menarik untuk terus membaca karya sastra. Dalam novel Bidadari Bermata Bening ini terdapat konflik yang menarik pembaca untuk terus membacanya karena dalam novel ini mengisahkan problematikan kehidupan sehari-hari yang dirasakan oleh manusia

\section{DAFTAR PUSTAKA}

Alzuardi, R., Priyadi, A. T., \& Muzammil, A. R. (2019). Konflik Tokoh Utama dalam Novel Tanah Surga Merah Karya Arafat Nur. Jurnal Pendidikan Dan Pembelajaran Khatulistiwa.

Aminudin. (2013). Pengantar Apresiasi Karya Sastra. Sinar Baru Algensindo.

Andari, N., \& Amalijah, E. (2018). Alur Novel Keindahan Dan Kesedihan Karya Kawabata Yasunari. Parafrase: Jurnal Kajian Kebahasaan \& Kesastraan, 18(01).

Diana, A. (2016). Analisis Konflik Batin Tokoh Utama dalam Novel Wanita di Lautan Sunyi Karya Nurul Asmayan. Jurnal Pesona.

Emzir. (2011). Metodologi Penelitian Kualitatif Analisis Data. Rajawali Press.

Etiwati, Syukur, L. O., \& Marwati. (2020). Konflik dalam Novel Cinta dalam Diam Karya Shineemink. Jurnal BASTRA (Bahasa Dan Sastra).

Harti. (2019). Psikologis Tokoh Utama dan Nilai Religius Novel Bidadari Bermata Bening Karya Habiburahman El-Shirazy. Diskursus: Jurnal Pendidikan Bahasa Indonesia.

Khusniyah, A. (2019). Perkembangan Puisi Cyber Sastra Di Indonesia. In Seminar Nasional Literasi IV (Vol. 4, No. 1).

Kosasih, E. (2012). Dasar-dasar Keterampilan Bersastra. Yrama Widya.

Meigita, E. (2018). Konflik Batin Tokoh Mei Rose dalam Novel Surga Yang Tak Dirindukan Karya Asma Nadia (Kajian Psikologi Sastra Kurt Lewin). Bapala, 5(1).

Moleong, L. J. (2007). Metodologi Penelitian Kualitatif Edisi Revisi. PT. Remaja Rosdakarya. Novenia, M., Taum, Y. Y., \& Adji, S. E. P. (2019). Strategi Dominasi dalam Novel Maryam

Karya Okky Madasari: Perspektif Pierre Bourdieu. Sintesis, 13(2), 102-111.

Nugraha, A. A. (2019). Konflik Sosial pada Novel Lelaki Harimau Karya Eka Kurniawan.

Prosiding SENASBASA (Seminar Nasional Bahasa Dan Sastra).

Nurgiyantoro, B. (2010). Teori Pengkajian Fiksi. Gadja Mada University Press.

Permata, K. A. W., Rasna, I. W., \& Nurjaya, I. G. (2014). Analisis Nilai-Nilai Kemanusiaan Novel "Bekisar Merah" Karya Ahmad Tohari dan Kesusuaiannya sebagai Bahan Pembelajaran Sastra. Pendidikan Bahasa dan Sastra Indonesia.

Ratna, N. K. (2009). Teori, Metode, dan Teknik Penelitian Sastra. Pustaka Pelajar.

Ristiana, K. R., \& Adeani, I. S. (2017). Konflik Batin Tokoh Utama dalam Novel Surga Yang Tak Dirindukan 2 Karya Asma Nadia. Jurnal Literasi.

Rohman, M. A. (2020). Konflik Batin Tokoh Utama dalam Novel Bidadari Bermata Bening: Kajian Psikologi Sastra dan Implementasinya sebagai Bahan Ajar Sastra di SMP.

Saputri, A., Thahar, H. E., \& Hayati, Y. (2016). Konflik Sosial pada Novel Warisan Karya Chairul Harun. Pendidikan Bahasa Indonesia. 
Semi, M. A. (1990). Anatomi Sastra. Angkasa Raya.

Siswanto, W. (2010). Pengantar Teori Sastra. PT Grasindo.

Sumardjo, J., \& K.M., S. (1994). Apresiasi Kesusastraan. PT Gramedia Pustaka Utama.

Widayanti, M. J. (2012). Komik sebagai Media Pengajaran untuk Meningkatkan Pemahaman Mahasiswa terhadap Narasi Cerita. Lembaran Ilmu Kependidikan, 41(2) 